\title{
CIRCUITIES OF PRIORITIES AND LIENS UNDER SECTION 67c(1) OF THE BANKRUPTCY ACT*
}

THE distribution of an insolvent's estate under the Bankruptcy Act follows a detailed order of payment designed to implement specific legislative aims. ${ }^{1}$ After holders of valid secured claims have been paid, ${ }^{2}$ section 64 allows certain classes of unsecured creditors to be paid in full before any general distribution is made. ${ }^{3}$ Benefiting all unsecured creditors, costs incurred in administering the estate receive first priority. ${ }^{4}$ Pre-bankruptcy wage claims have second priority because they are held by a class thought to need special protection.

*In re Quaker City Uniform Co., 238 F.2d 155 (3d Cir. 1956), cert. denied, 25 U.S.L. WeEk 3262 (U.S. Mar. 12, 1957) (Nos. 713, 717).

1. Bankruptcy Act $\S 64,30$ STAT. 563 (1898), as amended, 11 U.S.C. $\S 104$ (1952); $\S 65,30$ STAT. 563 (1898), as amended, 11 U.S.C. $\$ 105$ (1952); Chandler Act $\S 67 \mathrm{c}, 52$ STAT. 876 (1938), as amended, 11 U.S.C. \$ 107c (1952).

2. Except for statutory liens subordinated by $\$ 67 \mathrm{c}(1)$, the ordinary order of payment in bankruptcy is (1) secured claims, (2) priorities and (3) unsecured claims without priority. See In re Mount Holly Paper Co., 110 F.2d 220 (3d Cir. 1940) ; Middleton v. FidelityPhiladelphia Trust Co., 35 F.2d 851 (3d Cir. 1929). See 4 Collrer, Bankruptcy $\llbracket$ 67.20, at 188-89 (14th ed., Moore \& Oglebay 1956) (hereinafter cited as CollIER).

3. See 3 Collier $\{64.02$, at 2058. Section 65 provides for payment of a pro-rata share of the residue to all allowed but unsatisfied general claims, after assets have been set aside to pay secured creditors and priority holders under $\$ 64$. $3 i d$. $₫ 65.02$, at 2285 . Section 64 provides:

"[D]ebts which have priority.

(a) The debts to have priority, in advance of the payment of dividends to creditors ... shall be (1) the actual and necessary costs and expenses of preserving the estate ... the costs and expenses of administration ... ; (2) wages, not to exceed $\$ 600$ to each claimant, which have been earned within three months before [bankruptcy], due to workmen, servants, clerks, or traveling or city salesmen ...; (3) where the . . . bankrupt's discharge has been refused, revoked or set aside . . . at the cost and expense of ... creditors ... the reasonable costs and expenses of such creditors in obtaining such refusal, revocation, or setting aside ...; (4) taxes legally due and owing by the bankrupt to the United States or any state or any subdivision thereof ...; and (5) debts owing to any person including the United States, who by the laws of the United States in [sic] entitled to priority, and rent owing to a landlord who is entitled to priority by applicable State law: Provided, however, That such priority for rent ... shall be restricted to the rent ... which accrued within three months before the date of bankruptcy."

"Section 64 not only promotes equality of treatment regardless of regional variations in the theory of priority, but it provides an important channel for Congressional control of what may fairly be regarded as the primary aim of bankruptcy legislation-an equitable distribution of the debtor's assets to his creditors." 3 Colr.rer If 64.02, at 2053-54.

4. Section 64a (1). See 6 Remington, Bankruptcy $\$ 2640$ (5th ed. 1952) (hereinafter cited as REMINGTON).

5. See Blessing v. Blanchard, 223 Fed. 35, 37 (9th Cir. 1915) (loss of employment necessitates special status; shop superintendent but not general manager entitled to priority) ; In re Paradise Catering Corp., 36 F. Supp. 974, 975 (S.D.N.Y. 1941) (menial position and low income require protection; professional artist denied wage priority); In re Lawsam Elec. Co., 300 Fed. 736 (S.D.N.Y. 1924) (ignorance of employer's credit dictates 
Other classes of creditors take third, fourth and fifth priorities. ${ }^{b}$ But the first two priorities are given a further advantage. Under section $67 \mathrm{c}(1)$, added by the Chandler Act of 1938, certain secured claims valid against the trustee are postponed in payment to unsecured claims of costs and wages. ${ }^{7}$ The secured interests postponed are statutory liens on personalty unaccompanied by possession and liens of a landlord for unpaid rent. Congress subordinated these secured claims because, often accumulated over a long period, they frequently exhausted an inordinate share of the bankrupt's estate. ${ }^{8}$

Section $67 \mathrm{c}(1)$ 's selective subordination may create problems apparently unforeseen by Congress when, in addition to the priorities and the subordinated secured claims, an unsubordinated secured claim exists against the estate. ${ }^{9}$ Although ordinarily the unsubordinated secured claim would take first, ${ }^{10}$ a problem of circuity in distribution occurs when federal or state lien law requires that the subordinated claim be paid first. ${ }^{11}$ Usually there is no

favored treatment; chief de'signer not a "workman" or "servant"). See also 3 ColliER If 64.201, at 2083. The balance of a wage earner's claim exceeding $\$ 600$ earned within three months of bankruptcy will be a general unsecured claim. 3 id. at 2084 . See Note, 66 Y ALE L.J. 449, 460-61 (1957).

6. See note 3 supra. Although a third priority is not a creditor's claim in the strict sense, only a creditor of the bankrupt can qualify for the priority.

7. Section $67 \mathrm{c}$ reads:

"Where not enforced by sale before the filing of a petition [in bankruptcy] ... (1) ... statutory liens, including liens for taxes or debts owed to the United States or to any State or subdivision thereof, on personal property not accompanied by possession of such property, and liens whether statutory or not, of distress for rent shall be postponed in payment to the debts specified in clauses (1) and (2) of subdivision (a) of section [64] of this title and such liens for wages or for rent shall be restricted in the amount of their payment to the same extent as provided for wages and rent respectively in subdivision (a) of section [64]..."

The constitutionality of the section has been sustained against objection that $\$ 67 \mathrm{c}(1)$ deprived a landlord of property without due process of law. In re Jay \& Dee Store Co., 37 F. Supp. 989, 991 (E.D. Pa. 1941).

8. Section $67 \mathrm{~b}$ validates "statutory liens in favor of employees, contractors, mechanics, landlords, or other classes of persons, and statutory liens for taxes and debts owing the United States or to any State or any subdivision thereof. . . ." Of these, landlords' liens and tax liens were particularly troublesome:

"The Chandler Act ... adopted the view that a landlord should not be encouraged to accumulate liens of indefinite extent and thus contribute to building up unsound financial positions on the part of tenants to the disadvantage of general creditors. . . [.] Section $67 \mathrm{c}$ accordingly postponed such liens to administrative expenses and to vages. ..."

H.R. Rep. No. 2320, \$2d Cong., 2d Sess. 13 (1952). See also 6 Rexington \$ 2858, at 47374. And, as a result of long inaction of tax authorities, tax liens which had accumulated over a number of years often consumed a bankrupt's entire estate. 4 CoLLIER \ 67.20, at 189 .

9. See $4 i d$. at $196-97$.

10. See note 2 supra.

11. Circuities among liens were early recognized outside bankruptcy. See, e.g., Wilcocks v. Waln, 10 S. \& R. 380 (Pa. 1824); Dyson v. Simmons, 48 Md. 207 (1877); Goodbar \& Co. v. Dunn, 61. Miss. 618 (1884) ; Ferris v. Chic-Mint Gum Co., 14 Del. Ch. 232, 
difficulty in distributing the estate even with all three types of claim present. The unsubordinated lien (A) takes first, then the priority (B), and finally the subordinated lien (C). ${ }^{12}$ But if $\mathrm{C}$ is superior to $\mathrm{A}$ by applicable lien law, a circuity occurs. A is paramount to $B$, which is paramount to $C$, which in turn is paramount to $\mathrm{A}$. The following example illustrates the circuity: $\mathrm{A}$ holds an attachment lien, the trustee $B$ claims for costs and wages, and $C$ is the federal government with a tax lien on personalty unaccompanied by possession. Under federal lien law, $C$ should be paid before $A .{ }^{13}$ In bankruptcy $B$, ordinarily paid after $A$, is superior to $C$. A circuity results because two inconsistent standards for determining priority of payment appear to apply.

A recent case in the Third Circuit illustrates varying solutions to the problem of circuity. In re Quaker City Uniform Co. ${ }^{14}$ involved chattel mortgagees who had duly recorded, an unpaid landlord who had distrained on the bankrupt's personalty located on the leased premises, and the trustee in bankruptcy claiming for costs of administration and employees' wages. ${ }^{15}$ Between the mortgagee and trustee, the mortgagee should have prevailed since he held a valid lien normally unaffected by bankruptcy. ${ }^{16}$ Between trustee and landlord, the trustee should have prevailed under section $67 c(1) .{ }^{17}$ But by Pennsylvania

124 Atl. 577 (Ch. 1924) ; United States v. Texas, 314 U.S. 480 (1941). On the general problem, see 4 American Law of Property $\$ 17.33$, at 624-29 (1952) (isolating seven types of solution to circuities) ; Benson, Circuity of Lien-A Problem in Priorities, 19 MrNN. L. REv. 139 (1935) (suggesting a comprehensive solution for non-bankruptcy circuities), see note 56 infra; Kocourek, A First-Rate Legal Puzzle-A Problem in Priorities, 29 Ill. L. Rev. 952 (1935); Note, 38 Colum. L. Rev. 1267 (1938).

12. See In re Van Winkle, 49 F. Supp. 711 (W.D. Ky. 1943) (decision that unsubordinated lien is superior to subordinated lien by applicable lien law avoids circuity); cf. City of Richmond v. Bird, 249 U.S. 174 (1919), and In re Brannon, 62 F.2d 959 (5th Cir. 1933) (property subject to secured obligation not part of bankrupt's estate).

13. 4 COLLIER $\{67.24[2]$. The tax lien of the federal government is created by INT. REv. CoDE of 1954, $\$ 6321$.: "If any person liable to pay any tax neglects or refuse's to pay the same after demand, the amount ... shall be a lien in favor of the United States upon all property ... belonging to such person." Section 6322 provides that the lien imposed by $\S 6321$ "shall arise at the time the assessment is made. ..." Section 6323 makes the lien inoperative against mortgagees, pledgees, purchasers or judgment creditors whose interests in the property arise before notice is filed as the section prescribes. Whether prior or subsequent in time, the tax lien is superior, however, to attachment liens, United States v. Security Trust \& Sav. Bank, 340 U.S. 47 (1950); United States v. Acri, 348 U.S. 211 (1955), and to all "general liens," United States v. Liverpool \& London Ins. Co., 348 U.S. 215 (1955) (garnishment lien) ; United States v. Scovil, 348 U.S. 218 (1955) (landlord's lien perfected by distraint under state law). See Kennedy, The Relative Priority of the Federal Government: The Pernicious Career of the Inchoate and General Lien, 63 YALE L.J. 905,929 (1954).

14. 238 F.2d 155 (3d Cir. 1956), reversing 134 F. Supp. 596 (E.D. Pa. 1955).

15. Although there were two chattel mortgages involved, subsequent references will be to a single mortgage. The existence of more than one mortgage has no effect on the circuity.

16. City of Richmond v. Bird, 249 U.S. 174 (1919) ; In re Brannon, 62 F.2d 959 (5th Cir.), cert. denied, 289 U.S. 742 (1933) ; 3 CollIER $\uparrow$ 64.02, at 2055; see note 3 supra.

17. See note 7 supra and accompanying text. 
law, which gives the landlord's lien of distraint for rent priority over the mortgage, the landlord should have taken before the mortgagee: ${ }^{18}$ Apparently relying on a policy favoring protection of secured creditors, the referee in bankruptcy ordered that the mortgagee be paid in full before the other claimants were satisfied under section $67 \mathrm{c}(1) .{ }^{19}$ The district court, implicitly recognizing the circuity problem, went a step further. Accepting in part the referee's distribution, it permitted the landlord to be satisfied from the fund set aside for the mortgagee. ${ }^{20}$ In this manner the court attempted to satisfy state law. The court of appeals reached a third solution. It paid costs and wages first, then the landlord, and finally the mortgagee. Reading section $67 \mathrm{c}(1)$ broadly, it held that the mortgagee was subordinated to the landlord and therefore to the trustee "by necessary implication."21

The difficulties confronting the various courts in Quaker City have troubled other bankruptcy courts, whether the circuity was created by state lien law, as in the instant case, or by federal legislation. Thus, in two cases, bankruptcy

18. See In re Quaker City Uniform Co., 238 F.2d 155, 157 (3d Cir. 1956). PA. Stat. ANN. tit. 68, $\$ 250.302$ (Purdon Supp. 1956) confers the lien by distraint on the personalty of the tenant. Sections 321 and 322 preserve the landlord's lien after the goods come into possession of a receiver or trustee in bankruptcy, and give the landlord a right to priority of satisfaction from the proceeds of an execution. These sections have been uniformly construed to mean that a distraining Pennsylvania landlord has priority over chattel mortgagees, even where the mortgagee has filed notice before the landlord distrains. In re IIount Holly Paper Co., 110 F.2d 220 (3d Cir. 1940) ; In re De Lancey Stables Co., 170 Fed. 860 (E.D. Pa. 1909) ; Reinhart v. Gerhardt, 152 Pa. Super. 229, 31 A.2d 737 (1943); National Cash Register Co. v. Ansell, 125 Pa. Super. 309, 189 Atl. 738 (1937); Commercial Credit Plan v. Mahoney, 67 Pa. D. \& C. 577 (C.P. 1948). Cf. Matter of Townsend, 31 REF. J. 54 (1957) (Ref. E.D. Pa. 1956), holding a "security interest" subordinated to a landlord who had not distrained, and who had only a priority for rent, as distinguished from a lien, under Pa. Stat. AnN. tit. 39, $\$ 96$ (Purdon Supp. 1956).

Pennsylvania adopted the Uniform Commercial Code in 1954, id. tit. 12A, §10-101 (Purdon 1954), rewriting its commercial law to a great extent. Existing security devices, like the chattel mortgage, were not abolished, but merely brought under the rules of the Code. $I d$. § 9-102, at 336 (Code comment). Although all prior laws inconsistent with the provisions of the Code were repealed, $i d$. $\$ \$ 10-102-103$, the priorities given a landlord over holders of security interests such as the chattel mortgage appear to remain intact, id. $\$ 9$ 310, at 428-29 ( $\mathrm{Pa}$. Bar Ass'n notes) ; Herman v. Osgood, 103 P.L.J. 231 (County Ct. Pa. 1955) ; Matter of Townsend, supra.

Twenty-two states and the District of Columbia have statutes substantially similar to that of Pennsylvania giving a landlord a first lien, although some statutes apply only to personalty, some to crops, and some to both. See, e.g., ALA. CoDE tit. 31, $\$ \S 15,29$ (Supp. 1955) (crops and personalty), Colvin v. Payne, 218 Ala. 341, 118 So. 578 (1928); FLA. Stat. ANn. \& 83.08 (Supp. 1956) (same), Pillans \& Smith Co. v. Lowe, 117 Fla. 249, 157 So. 649 (1934); Iowa CODE ANN. $\$ 570.1$ (Supp. 1956) (crops and personalty), Dilenbeck v. Security Sav. Bank, 186 Iowa 308, 169 N.W. 675 (1918) ; KAN. GEN. STar. § 67524 (1949) (crops), Shell v. Guthrie, 129 Kan. 632, 284 Pac. 420 (1930).

19. Opinion of the Referee, reprinted in Brief for Appellant, pp. 14a-22a, In re Quaker City Uniform Co., 238 F.2d 155 (3d Cir. 1956). For discussion of the referee's opinion, see note 35 infra.

20. $134 \mathrm{~F}$. Supp. at 598.

21. 238 F.2d at $159-60$. 
courts were confronted with a circuity when a state tax lien accompanied by possession, the trustee's claims for costs and wages, and a federal tax lien unaccompanied by possession conflicted. Under lien law, the federal tax lien was superior to the state lien. Under $67 \mathrm{c}(1)$, the federal lien was inferior to the cost and wage claims. One court ordered full payment of the state's claim first, ${ }^{22}$ while the other restricted the state's recovery to the fund available less the amount claimed by the federal lien. ${ }^{23}$ In other cases, as in Quaker City, consensual liens conflicted with claims of the trustee and with state statutory liens unaccompanied by possession. ${ }^{24}$ Again, under similar facts, different distributions were ordered. ${ }^{25}$ And, whether recognizing the circuity or not, the courts seldom gave sound reasons for their distributions. While all the decisions involved proceedings under the Bankruptcy Act, none undertook a thorough analysis of section $67 \mathrm{c}(1)$ and its underlying policies, by which the ultimate order of distribution should be determined.

Any consideration of section $67 \mathrm{c}(1)$ to determine the most desirable distribution of assets in circuity situations should attempt to balance the three main interests affected. The section explicitly treats two of these: the interests of cost and wage claimants and of the states and federal government in preserving a prescribed order of payment among lienholders. The third interest, that of a lienor unsubordinated by section $67 \mathrm{c}(1)$, is affected implicitly by the section; such creditors are concerned in the distribution ordered only when, as in Quaker City, circuities occur. Congress clearly intended to benefit unsecured claims for wages and administrative costs in giving them preference to certain statutory lienholders. But the section's failure to regulate the priority of liens inter se suggests that weight be given to state and federal lien law whenever possible. ${ }^{26}$ 'True, Congress did not intend to retain non-bankruptcy lien prior-

22. In re Ann Arbor Brewing Co., 110 F. Supp. 111 (E.D. Mich. 1951) (city, county and district taxes paid first, then costs and wages before federal tax lien superior to other tax liens under federal law). Admitting the case was difficult, the court held that the possessory state liens were "not to be subordinated to administration expenses and labor claims. .. ," giving no further reason for the decision. Id. at 117.

23. California Dep't of Employment v. United States, 210 F.2d 242, 244 (9th Cir. 1954). The court set aside an amount equal to the federal tax lien, paying the priorities from that amount. Since the federal lien exceeded the fund, nothing was left for the state liens accompanied by possession.

24. See New Orleans v. Harrell, 134 F.2d 399 (5th Cir. 1943) (chattel mortgage paid first, then costs and wages before city tax lien superior to mortgagee under state law); In re Empire Granite Co., 42 F. Supp. 450 (M.D. Ga 1942) (bill of sale to secure a debt paid first, then costs and wages, then state tax liens superior to bill of sale under state law; but the amount recovered under the bill of sale was limited to the fund minus the superior tax liens).

25. The cases cited in note 24 supra both arose in the Fifth Circuit. In Empire Granite the district court paid the unsubordinated lienor first, but only to the extent of the fund minus the liens superior under state law. $42 \mathrm{~F}$. Supp. at 458 . Although approved in Feigenbaum, Tax Problems, 25 REF. J. 107, 111. (1951), the case had been implicitly overruled by the court of appeals in Harrell, which paid the unsubordinated lienor first out of the full fund. 134 F.2d at 400 .

26. Se'e 4 Colcter If 67.27 , at 296; 4 id. $\{$ 70.70, at 1347 (Supp. 1956). 
ities unqualifiedly, ${ }^{27}$ since some statutory liens are subordinated under $67 \mathrm{c}(1)$ and may even be invalidated under $67 \mathrm{c}(2) .^{28}$ But to the extent a lien subordinated by section $67 c(1)$ is not invalidated by section $67 c(2)$, a state or federal interest in preserving a priority of liens exists. Moreover, for those liens invalidated as well as subordinated, a substituted interest in maintaining lien priority arises in the trustee, representing the bankrupt's estate, since section $67 \mathrm{c}(2)$ "preserves" invalidated liens and the excess of restricted subordinated liens for the benefit of general creditors. ${ }^{29}$ For example, the landlord's lien in Quaker City, limited in payment to three months' rent, ${ }^{30}$ is one of those section $67 \mathrm{c}(1)$ restricts, the trustee obtaining an interest in the excess of the lien over three months rent; a similar interest exists as to liens entirely invalidated, such as state tax liens. ${ }^{31}$ Accordingly, two interests are dealt with by section $67 \mathrm{c}(1)$ : that in protecting cost and wage priorities and that in re-

27. See note 7 supra.

Section $67 \mathrm{c}(2)$ provides:

"... statutory liens created or recognized by the laws of any state for debts owing to any person, including any State or subdivision thereof, on personal property not accompanied by possession of, or by levy upon or by sequestration or distraint of, such property, shall not be valid against the trustee... The court may on due notice order so much of any lien in excess of the restricted amount under clause (1) of this subdivision and any lien invalid under clause (2) of this subdivision to be preserved for the benefit of the estate and, in any such event, such lien for the excess and such invalid lien ... shall pass to the trustee."

66 STAT. 428 , 11 U.S.C. $\$ 107 \mathrm{c}(2)$ (1952).

28. Certain classes of liens subordinated by clause (1) are not invalidated by clause (2) : federal statutory liens on personalty unaccompanied by possession; state statutory liens unaccompanied by possession, but accompanied by levy, sequestration or distraint; and landlord's liens of distress for rent. 4 CollIER $\llbracket$ 67.281, at 311-12. Because most state liens would also be possessory if accompanied by levy, sequestration or distraint, the chief group of liens subordinated without invalidation are federal. All liens subject to invalidation by clause (2) would be subject to subordination under the broader language of clause (1). Ibid.

29. See note 27 supra. "Preservation" assures that funds from an invalidated lien will benefit general creditors, rather than a junior lienholder. See 4 CoLLIER ff 67.281, at 314 .

30. There is some doubt whether a landlord may claim three months' rent as a lienholder, while retaining priority status for an additional three months' rent. Section 64a(5) restricts the landlord's priority to rent "owing for the actual use and occupancy of the premises, and which accrued within three months before the date of bankruptcy." Section $67 c(1)$ restricts the landlord's lien in the amount of its payment to the same extent the priority is restricted by the earlier section. The two sections read together seem to call for a disallowance of the priority claim when payment of the lien has satisfied the three months covered. This result accords with congressional disapproval of preferential treatment granted landlords by the states. See 6 ReMrington $\S 2858$. But at least one court has awarded a landlord his priority claim in addition to his lien. In re Allen, $92 \mathrm{~F}$. Supp. 717 (S.D. Tex. 1950), criticized in 4 Collier If 67.28, at 308 n.17a.

31. Cf. Matter of Gordon, 27 REF. J. 85 (1953) (Ref. E.D. Mich. 1952) (invalidating city, county and state tax liens unaccompanied by possession or process). But cf. 4 ColiIER If 67.281, at 312-13, suggesting but rejecting an ambiguity in the term "debts" in $\S 67 \mathrm{c}(2)$ which might lead a court to exclude state tax liens from the invalidation provision of the section. 
taining the order of lien priorities, whether claimed by the subordinated lienor or, the trustee under section $67 \mathrm{c}(2)$.

Finally, section $67 \mathrm{c}(1)$ 's subordination of some statutory liens seems to indicate acceptance of the prior rights of consensual secured creditors, judicial lienors and unaffected statutory lienors. In allowing such creditors to take first, the Bankruptcy Act implies that their expectations should be satisfied before those of general creditors. This approach displays a concern for the creditor who gives value on the basis of specific security or attaches specific property and, in a broader sense, for protection of the credit market. ${ }^{32}$ Thus the mortgagee may expect his claim to be superior to those of general creditors. He knowingly incurs the risk, however, that local law will give preference to another lien, although subsequently perfected..$^{33}$ With the amount of the mortgage as an upper limit, the mortgagee's expectation is therefore the value of the property less the amount of any state-created lien taking precedence over his claim. ${ }^{34}$ A solution is needed to satisfy concurrently the intent of Congress to benefit cost and wage claimants, the demand of state and federal governments to maintain their lien priorities, and the expectation of unsubordinated lienors to be paid before general creditors.

Although each distribution in Quaker City is based on some statutory or policy foundation, none adequately reconciles the three conflicting interests. Initially, the referee declared the mortgagee's claim unaffected by sections 64 and 67 of the act, the mortgaged property not being part of the bankrupt's estate. To support full payment of this claim first he apparently reasoned in two steps. He cited cases which indicated that he considered the landlord's lien not perfected in a federal sense, regardless of state law, because section $67 \mathrm{c}$ (1) subordinated this lien to the first two priorities. ${ }^{35}$ Then, in order to subordinate the landlord's superior lien to the mortgage, he held the land-

32. Cf. the 1950 revision of $\$ 60,64$ STAT. 24 (1950), 11 U.S.C. $\$ 96$ (1952), dealing with the "preference" problems arising out of such cases as Corn Exchange Nat'l Bank v. Klauder, 318 U.S. 434 (1943), and In re Vardaman Shoe Co., 52 F. Supp. 562 (E.D. Mo. 1943). See H.R. Rep. No. 1293, 81st Cong., 1st Sess. 3 (1949).

Section $67 \mathrm{c}(1)$ itself attaches some significance to the specificity concept by subordinating only liens unaccompanied by possession and unlimited in their application to a debtor's property. See notes 7 and 8 supra.

33. See Osborne, Mortgages $\$ 221$, at 596-97 (1951):

"There are a considerable number of liens ... which are created, or at least notice of which is provided for, by statute that constitute risks of which a mortgagee must take account. ... The hazards of . . . displacement constitute a normal risk that the mortgagee runs and enters into his calculations."

See note 18 supra.

34. Hereinafter, references to the mortgagee's or other unsubordinated lienor's expectation will assume that the property is insufficient to satisfy all liens.

35. Opinion of the Referee, reprinted in Brief for Appellant, pp. 14a-22a, In re Quaker City Uniform Co., 238 F.2d 155 (3d Cir. 1956). The referee pointed to cases in which a federal tax lien was held superior to a "general" lien. E.g., United States v. Scovil, 348 U.S. 218 (1955) (landlord's lien by distraint inferior to tax lien), and other cases cited note 14 supra. These cases, however, appear unnecessary to subordinate the landlord to 
lord's lien unperfected as to the lien of the mortgagee as well. ${ }^{36}$ His approach thus avoided the circuity by disregarding the state-determined lien priority. Since the referee's solution pays a mortgagee in full, even though his expectation is only the fund less the landlord's lien, the mortgagee receives a windfall at the expense of other claimants whenever the fund is less than the sum of . the mortgagee's and landlord's claims. ${ }^{37}$ Moreover, even though section $67 \mathrm{c}(1)$ attempts to benefit the priorities, the mortgagee's windfall is at the expense of the priorities when the fund is also less than the sum of the mortgage and priorities. ${ }^{38}$

In an effort to reconcile state law with the provisions of section $67 c(1)$, the district court paid the mortgagee first but allowed the landlord to take from that amount. ${ }^{39}$ The priorities were paid next. This distribution permitted the landlord to do indirectly what he could not have done directly-take before the priorities. ${ }^{40}$ Furthermore, since the mortgagee's expectation equals the fund

the priorities in Quaker City, since $\S 67 \mathrm{c}(1)$ dictates as much. The referee apparently relied on the tax cases to indicate he was free to hold the landlord's lien unperfected as to the chattel mortgage, since its perfection was determined by federal law. See note 36 infra.

36. After discussing the cases cited in notes 14 and 35 supra, the referee said:

"The foregoing review of authorities has been made because the position of lien claimants and priority claimants must be viewed in the light of the federal law. If the state law were to prevail ... the Pennsylvania distribution would be as follows:

"1. Landlord

2. Chattel mortgages

3. Wage claims... [citing cases]

"Accordingly, the Referee ... holds that the chattel mortgages . . . must be first paid. ... Second to be paid out will be administration expenses, then come ... the ... wage claims and then the landlord."

Brief for Appellant, In re Quaker City Unniform Co., supra note 35, at 21a. (Emphasis added.)

37. Although the circuity existed as to the specific property mortgaged, the word "fund" is hereinafter used, since in Quaker City the property was sold and the proceeds constituted the bulk of the bankrupt's estate. 238 F.2d at 157 n.1.

38. Assume a fund of 3 , a mortgage of 3 , priorities of 2 and a landlord's lien of 2 . Outside bankruptcy, the mortgagee would take only 1-what remained after paying the landlord in full. The referee's distribution gives the mortgagee the entire fund. If the fund were 5 or more however, this solution would not confer a windfall on the mortgagee, since he could expect full payment outside bankruptcy.

39. It does not appear in the district court's opinion what standing the mortgagee would have for the unsatisfied portion of his claim. Presumably the mortgagee would be subrogated to the rights of the landlord and take after costs and wages. But if the landlord had not recovered his entire claim from the amount paid the mortgagee, the court's concern for state law suggests that the landlord would be paid in full before the mortgagee could take at all. In fact, the court indicated the landlord would take, but did not discuss the mortgagee's pasition. $134 \mathrm{~F}$. Supp. at 598 .

40. Assume a fund of 3 , a mortgage of 3 , priorities of 2 and a landlord's lien of 2 . See note 38 supra. The district court's distribution gives the mortgagee 1 and the landlord 2 . Costs and wages get nothing, and it might be suggested that this is proper, since they were subsequent to a claim (the mortgage) which equalled the fund. Yet the result clearly preiers the landlord, who is paid in full, to the priority holders, who get nothing. 
less the landlord's lien, the district court's distribution, giving him his mortgage less the landlord's lien, will prejudice his expectation whenever the fund is greater than the mortgage. ${ }^{41}$ This interpretation thus subordinates not the landlord, but the mortgagee to the priorities, to the extent his claim is paid to - the landlord. ${ }^{42}$

The court of appeals was of the opinion that section $67 \mathrm{c}(1)$ could be satisfied only by subordinating everyone to costs and wages. Because the mortgagee was inferior to the landlord under state law, and the landlord was inferior to the priorities under section $67 \mathrm{c}(1)$, the mortgagee was held subordinated to the priorities as well as to the landlord. ${ }^{43}$ This distribution gives greatest weight to the policy of benefiting claimants for costs and wages. ${ }^{44}$ But

41. For example, if the fund was 6 and the mortgagee, priority holders and landlord each claimed 3, the mortgagee could expect full payment outside bankruptcy. Yet the district court's distribution leaves him nothing.

42. If the fund was 6 , and the mortgagee, priority holders and landlord each claimed 3 , outside bankruptcy the landlord and mortgagee each take 3 . In bankruptcy, the landlord and priorities each take 3 .

43. 238 F.2d at $159-60$.

In an opinion subsequently withdrawn, the court held originally that in Pennsylvania a chattel mortgage was a statutory lien within the meaning of $\$ 67 \mathrm{c}(1)$ and was thus explicitly subordinated to the priorities. $2 \mathrm{CCH}$ BANKR. L. REP. (4th e'd.) If 58778 (3d Cir. 1956). The holding that the chattel mortgage is a statutory lien avoided the circuity problem by placing mortgagee and landlord in the same category of claimants subordinated to the first two priorities, where state law could govern between them without difficulty. But a chattel mortgage is not a statutory lien. See 4 Collrer 167.20 , at 184-85; New Orleans v. Harrell, 134 F.2d 399 (5th Cir. 1943) (implicit holding); cf. In the Matter of Tele-tone Radio Corp., 133 F. Supp. 739, 748 (D.N.J. 1955) (factor's lien not "statutory" lien). And faced with the possibility that a chattel mortgage might be invalid against the trustee under $\S 67 \mathrm{c}(2)$ if held a statutory lien within the meaning of $\$ 67 \mathrm{c}(1)$, the court on rehearing ordered the same distribution, but under the "necessary implication" theory. 238 F.2d at 159. It was thus no longer necessary to decide the statutory lien question. Id. at 157.

44. In support of the necessary implication theory, the court cited only one case, In re Michael's Cafeteria, 49 F. Supp. 657, modified on rehearing, 52 F. Supp. 799 (W.D. La. 1943); see 238 F.2d at 160 n.7. But Michael's, although not entirely clear, does not appear to support the proposition it was cited for. The bankrupt's landlord held a rent lien superior to a chattel mortgage, which was in turn superior to a federal government tax priority. The chief question was whether the landlord could take his entire claim, or whether he was restricted to three months' rent. At that time, $\S 67 \mathrm{c}(1)$ allowed the landlord only three months' rent "except as against other liens." 52 STAr. 877 (1938). See In re Eakins Lumber Co., 39 F. Supp. 787 (N.D. W. Va. 1941). 'The court first allowed the landlord to take three months' rent plus the amount of the inferior mortgage, leaving the remainder of the fund for the tax priority. $49 \mathrm{~F}$. Supp. at 658 . On rehearing, the court decided that the Chandler Act did not apply, since the lease antedated its enactment. Cost and wage priorities were paid; the landlord then took the entire remainder of the fund to satisfy his rent lien.

Michael's Cafeteria has been interpreted as "apparently" subordinating a mortgagee to "administrative and wage claims" of $\$ 64.4$ CoLLIER \ 67.27, at 297 n.41. But neither opinion in that case considered the status of cost and wage priorities, and the mortgagee involved did not appeal to contest his "subordination" to those claimants. In fact, it was 
since the mortgagee is paid only his expectation (the fund less the landlord's lien) less the priority claims, the distribution impairs that expectation whenever the fund is insufficient to satisfy all claims. ${ }^{45}$ Moreover, the "necessary implication" rationale has no compelling logic in terms of statutory language; it could equally well be argued-as the referee assumed-that by its silence Congress intended the mortgagees to be paid in full first. ${ }^{46}$ Nor is the implication "necessary" in the sense that no other distribution could better satisfy the conflicting interests implicit in section $67 \mathrm{c}(1)$.

The most satisfactory solution pays the unsubordinated lienor's expectation first and then applies section $67 \mathrm{c}(1)$ to the interests it explicitly affects. ${ }^{47}$ The priorities, paid next from the remaining fund, are subordinated only to an interest against which they were never considered to have a prior claim. Conceptually, the subordinated lien is preserved above the unsubordinated lien for the benefit of the priorities. This achieves an effect consistent with the intent of section $67 \mathrm{c}(1) .{ }^{48}$ The priorities recover from the very fund provided for

alleged that the mortgagee had been paid by an endorser of the mortgage. The endorser did not appear, although he would have been subrogated to the rights of the mortgagee. $52 \mathrm{~F}$. Supp. at 800 . Thus, the apparent subordination of the mortgagee to the priorities relied on by the Third Circuit was never adequately considered, nor is there any indication what the Michael's Cafeteria court would have held, had they been presented with the issue.

45. Assume a fund of 6 , with claims of 3 apiece by a mortgagee, priority holder and landiord. See note 41 supra. The court of appeals' distribution would give the mortgagee nothing. If the landlord's lien had been 6 , however, even though the amount taken would be the same, the mortgagee could not complain.

46. In an early case, Andrus v. Burke, 61 N.J. Eq. 297, 299, 48 Atl. 228, 229 (Ch. 1901), one judge remarked that he was "taught while a law student that the legal puzzle presented by the [circuity] situation was insoluble on any known principles." Thus the characteristic approach of courts has been to break the circle at random. Benson, Circuity of Licn-A Problem in Priorities, 19 MrNw. L. Rev. 139, 146 (1935). The "necessary implication" rationale does just that. Its reasoning is intuitively syllogistic: $A$ is prior to $B$; $B$ is prior to $C$; therefore $A$ is prior to $C$. One difficulty with this approach is that the results vary depending on which letters the courts ascribe to the different parties. While the referee in Quaker City treated the mortgagee as $\mathrm{A}$, costs and wages as $\mathrm{B}$ and the landlord as $C$, the court of appeals treated costs and wages as $A$, the landlord as $B$ and the mortgagee as $\mathrm{C}$.

47. The text proposal was indicated in California Dep't of Employment v. United States, 210 F.2d 242 (9th Cir. 1954), explaining the distribution on the theory that " 67 sub. c does not affect or impair the priorities of liens recognized by $\S 67$ sub. b." There state tax liens were superior to administrative costs, which were superior to a federal tax lien subordinated by $\$ 67 \mathrm{c}(1)$, and the court found the federal lien superior to the state liens. The court paid the federal lien first, allowing the priorities to be satisfied from this amount. Because the federal lien exceeded the fund available, the state took nothing; yet the court indicated that had the federal lien been less than the fund, the state would have taken the remainder. Id. at 244.

See also In re Empire Granite Co., 42 F. Supp. 450 (M.D. Ga. 1942), adopting a similar solution, discussed at note 25 supra.

48. In Quakcr City the court of appeals considered and rejected the proposed solution: "The difficulty presented by this solution is that the superior lien will be defeated to the extent of the administrative expenses and wage claims. ... The wage claims 
them; the unsubordinated lienor is not affected by $67 \mathrm{c}(1)$ which was not intended to reach him. Only the subordinated lienor, whether actually represented by the lienholder or by the trustee substituted for him, may seriously object to this distribution. Although preferred under ordinary lien law, he is never paid in full, and under some facts the unsubordinated lienor may be paid, while the subordinated lienor is unsatisfied. ${ }^{49}$ However, he is adversely affected only to the advantage of the priorities, a result consistent with the tenor of the section. In Quaker City, for example, the mortgagee does not benefit at the expense of the landlord's ultimate claim for three months rent and the trustee's claim for the excess since the mortgagee receives only the share remaining had the landlord taken outside bankruptcy. ${ }^{50}$ Finally, the unsubordinated lienor is

asserted in this case would consume the entire amount set aside for the landlord and even worse than the fear of merely upsetting state lien priority, the application of the rule in this case would completely destroy the superior state lien."

$238 \mathrm{~F} .2 \mathrm{~d}$ at 159 . But $\S 67 \mathrm{c}(1)$ specifically intends the defeat of the landlord's lien for the benefit of administrative expenses and wage claims. H.R. REP. No. 2320, $82 \mathrm{~d}$ Cong., $2 \mathrm{~d}$ Sess. 13 (1952). Moreover, although the court rejected California Dep't of Employment, supra note 47 , because the superior lien would be "destroyed," the "necessary implication" solution also dictated first payment to costs and wages, the landlord taking nothing. 238 F.2d at 160 .

49. Three types of subordinated lien may be adversely affected by the proposed solution: federal tax liens on personalty, state and local statutory liens unaccompanied by possession, but accompanied by levy, sequestration or distraint, and landlords' liens of distress for rent. See note 31 supra. Of these, a landlord may have no complaint if the fund is great enough to satisfy his claim for three months rent-the maximum allowed by $\$ 67 \mathrm{c}(1)$ -after payment of the unsubordinated lienor's expectation and the priorities. In general, however, after payment of the unsubordinated lienor's expectation (fund minus subordinated lien) only an amount equal to the subordinated lien remains for distribution. The existence of any priority claims for costs and wages will diminish the subordinated lienor's share pro tanto. Further, if the fund is less than the priorities plus the unsubordinated lienor's expectation, the subordinated lienor takes nothing. For example, if the fund were 3 , and the claims of the mortgagee, priority holder and landlord each 2, the mortgagee would take 1 and the priority holder 2, leaving nothing for the landlord.

50. Applying these principles to the actual case, the proposed distribution in Quaker City follows:

\begin{tabular}{lrr} 
& \multicolumn{1}{c}{ Claims } & Amounts paid \\
Fund $\quad \$ 9,896.77$ & & \\
Chattel Mortgagee (1) & $\$ 3,480.00$ & $\$ 3,480.00$ \\
Chattel Mortgagee (2) & $2,612.80$ & $2,612.80$ \\
Costs and Wages & $11,738.13$ & $3,803.97$ \\
Landlord & $3,641.07$ & \\
& & $\$ 9,896.77$
\end{tabular}

Both mortgagees are paid in full because they expected to receive full payment outside bankruptcy. But this is not to say what the referee implied-that the mortgagee should be paid first in any case. For example, if the amounts claimed by the landiord and first mortgagee had been greater than $\$ 7,283.97$, the amount taken by the second mortgagee would decrease accordingly. 
not prejudiced, for when his expectation is less than his full claim, he is a general creditor for the difference. ${ }^{51}$

The proposed method of distribution seemingly encourages accumulation of the subordinated lien. With a given fund, the unsubordinated lienor's expectation varies inversely with the size of the subordinated lien until the latter equals the fund. Consequently, any reduction in the unsubordinated lienor's expectation, which would result from accumulation of the subordinated lien, leaves greater assets remaining for other distributees, including the subordinated lienor. ${ }^{62}$ It is doubtful that the inducement factor would be strong, however. Pressures exist to prevent the subordinated lienor from allowing his claim to accumulate. In the case of a landlord, he will prefer to foreclose his lien, evict the tenant, and re-rent to one who does not appear to be insolvent. Further, since section $67 \mathrm{c}(1)$ restricts the landlord's lien to three months rent and the trustee takes the excess, the landlord has little to gain by allowing accumulation beyond that amount plus the amount of cost and wage claims. ${ }^{53}$ And because he will always be uncertain of the exact amount of these priorities, attempts to determine the best time to foreclose would be hazardous. All other subordinated liens save one are likewise invalidated at least in part; only a federal statutory lien-normally for taxes-is not affected by section $67 \mathrm{c}(2) .^{54}$ But because the federal lien occupies a varying position as against other liens, depending on their nature and date of recordation, ${ }^{55}$ the existence of substantial motivation to accumulate rather than foreclose is questionable. Thus, the dependence of one claimant's share upon the size of other claims should not im-

51. Bankruptcy Act $\$ 57 \mathrm{~h}, 30$ STAT. 560 (1898), 11 U.S.C. $\$ 93 \mathrm{~h}$ (1952). See United States Nat'l Bank v. Chase Nat'1 Bank, 331 U.S. 28 (1947) ; 3 CoLsIer ff 57.07, at 149-57, Tf 57.20, at 255-59.

The problem of how to treat the unpaid portion of an unsubordinated lien arises only where the fund remaining after payment of his expectation is more than enough to pay cost and wage claims and the uninvalidated subordinated lien. The unsubordinated lienor can take only as a general creditor from the invalidated lien since $\$ 67 \mathrm{c}(2)$ preserves it for general creditors. After the priorities are paid in full, the subordinated lienor will have first claim against any residue. There is no longer any reason to pay the unsubordinated lienor, who has already recovered his non-bankruptcy expectation, until the claimant superior under non-bankruptcy law is satisfied.

52. By the same reasoning, costs and wages benefit to a greater degree from an increase in the subordinated lien since they will take first out of the fund remaining after payment to the unsubordinated lienor. Where the subordinated lien is also invalidated, the general creditors benefit by any increase, since the invalidated lien will be preserved by the trustee.

53. Section $67 \mathrm{c}(1)$ provides: "liens for ... rent shall be restricted in the amount of their payment to the same extent as provided ... in subdivision [a] of section $64 . .$. " But in computing the mortgagee's expectation outside bankruptcy, the total amount of the landlord's lien allowed by state law should be considered, and not only the amount accruing within three months of bankruptcy. The mortgagee cannot complain of this treatment, since he should be neither harmed nor benefited by $\S 67 \mathrm{c}(1)$.

54. Unless nonpossessory state liens are accompanied by levy, sequestration or distraint, they are invalidated by $\$ 67 \mathrm{c}(2)$. See note 28 supra.

55. See note 13 supra. 
pede acceptance of the proposed solution, particularly when it furthers the objective of fulfilling the parties' expectations to the fund. ${ }^{58}$

56. A solution based entirely on the parties' expectations is proposed by Benson, Circuity of Lien-A Problem in Priorities, 19 MrNw. L. Rev. 139 (1935). Benson suggests that each party in a circuity stands in the position of a junior lienholder, and should be paid on the basis of his expectation-the fund less any claims directly superior to his claim. Although criticized for its complexity (Kocourek, supra note 11, at 953) Benson's solution appears desirable in non-bankruptcy situations. In a $\$ 67 \mathrm{c}(1)$ circuity, however, the solution leads to results not reconcilable with the congressional intent to subordinate selected liens to costs and wages. If the unsubordinated lien is equal to the fund, the priorities have no expectation, and by Benson's solution might take nothing while the subordinated lien might be paid, even in full. For example, with a fund of 3 , a chattel mortgage of 3 , costs of 1 and a landlord's lien of 2 , the chattel mortgage expects and receives 1 , since he is inferior to a claim of 2 . The landlord expects and receives 2 , since he is inferior to a claim of 1 . Costs, on the other hand, expect and take nothing, since they are inferior to a claim equaling the fund. 